\title{
Pension and retirement intentions as determinants of employee engagement and productivity
}

\author{
Nur Hasan Kurniawan ${ }^{a *}$, Mahmuddin $\operatorname{Yasin}^{\mathrm{b}}$ and Hamidah ${ }^{\mathrm{c}}$
}

${ }^{a}$ Student of Doctoral Program in Human Resource Management, State University of Jakarta, Jakarta, Indonesia

${ }^{b}$ Lecturer, State University of Jakarta, Jakarta, Indonesia

${ }^{c}$ Lecturer, State University of Jakarta, Jakarta, Indonesia

\section{H R O N I C L E}

\section{Article history:}

Received: September 18, 2020

Received in revised format:

November 182020

Accepted: December 12, 2020

Available online:

December 15, 2020

Keywords:

Pension funds

Occupational pension scheme

Retirement intentions

Employee engagement

Employee productivity

\section{Introduction}

The trend of worker participation in pension fund programs in Indonesia is relatively low. The number of active workers in the formal sector currently reaches about 50 million people, but only 17.8 million $(35.6 \%)$ pension schemes are organized by the government such as BPJS Ketenagakerjaan (Social security BPJS Employment) and Taspen (Pension Fund for Indonesia Civil Servant), ASABRI (Pension Fund for Indonesia Military and Police) as well as the Employer Pension Fund, the Financial Institution Pension Fund. This trend is different from the trend in many countries. Whereas nearly half of all workers in many countries participate in pension plans, with the average pension plan contribution being about five percent of the salary set by employers (Wang et al., 2018). The low participation of workers in pension fund programs in Indonesia is related to various causes. One of them is related to inadequate employee pension schemes or occupational pension schemes (OPS), or dues that burden employees finances (Gough \& Hick, 2009). Low interest in employees joining the pension fund program, can also be related to the level of knowledge about different OPS features, seen from different response patterns, levels of awareness and expectations among workers (Loretto et al., 2000). The occupational pension scheme (OPS) and its implications on other variables need to be reviewed, as research gaps have been found in previous studies. The research gap is: (i) OPS has a positive effect on retirement intentions or retirement intentions (RI) (Ahmad et al., 2013; Garcés-Galdeano et al., 2016). However, according to Dorsey et al. (1998) OPS can prevent workers from quitting; (Gough \& Hick, 2009) the extent to which OPS

* Corresponding author. Tel.: +62 8161859517

E-mail address: nur.hasan.kur@gmail.com (N. H. Kurniawan) 
affects the RI depends on how the structure of the retirement plan created by the organization may affect the behavior of workers.

(ii) Guaranteed pension packages will further strengthen employee engagement (EE) (Colquitt et al., 2014; Hoole \& Hotz, 2016). However, Kim and Cho (2016) state that regarding the implications of the retirement system on worker behavior, among others depends on the monetary variable system (such as salaries, incentives, pensions) applied by the organization. (iii) The old day guarantee positively affects the performance of workers (Bossler, 2015; Colquitt et al., 2014; Cornwell \& Dorsey, 2000; Dorsey et al., 1998; Mukundi, 2016; Oloke et al., 2017a). Nevertheless, Alda and Ferruz (2012) state that pension funds can improve worker performance such as employee productivity or employee productivity (EP) is depending on the type of pension fund, which is a matter of low-cost pension funds felt by workers. (iv) There is a positive influence of RI on EE (Rusyandi, 2015; Saks, 2006; Solem et al., 2016). While research in Malaysia shows the minimal influence of RI on EE (Hussain et al., 2013). Based on the research gap, the authors are interested in integrating these four variables (OPS, RI, EE, EP) in a research model. Empirically the location of the study was reviewed at one of the pension institutions, in this case the Joint Retirement Fund of the Joint Pension Fund of municipal waterwork throughout Indonesia (Dapenma-Pamsi). As a pre-study of this study, with technical considerations, researchers chose this pre-study location at Dapenma-Pamsi in DKI Jakarta. Pre-study was conducted by distributing questionnaires to 30 respondents according to population criteria. Prestudies conducted, in addition to obtaining instrument tests (validity tests, reliability tests), also resulted in descriptive analysis of all four variables (OPS, RI, EE, and EP), as well as analysis of causal relationships between variables. The pre-study results showed that of the four variables (OPS, RI, EE, EP), the highest approval rate $(81.3 \%)$ belongs to the details of the statement in the questionnaire which are associated with employee productivity (EP). Meanwhile, the respondent's lowest approval rate on the details of the statement in the questionnaire was on the retirement intentions (RI) variable which only reached $36.0 \%$. This indicates that there are serious problems with RI in these pre-study respondents but in general, the respondent's approval rate for the overall questionnaire items is also still relatively low, the average for all four variables is $67.1 \%$. This means that there is not a single research variable whose respondent's percentage value belongs to the category of Agree, let alone Strongly agree. This indicates that there is still a problem in the respondent regarding the four variables, so that it is feasible and significant. The next pre-study result was a causal relationship of the four variables (OPS, RI, EE, and EP). This pre study is intended to test at an early stage the construct of these variables on respondents' perceptions, whether there is a causal relationship or not. The results of this pre-study showed that all of them had an effect on their respective relationships, although some had a negative effect (OPS on EPs). Judging by the significance aspect, only two relationships have a significant effect (OPS on EE; and EE to EP); while other inter-variable relationships show insignificant influence. Based on the results of the press-study, there is a problem regarding the relationship between pension variables (OPS and RI) with common HR variables (EE and EP). Therefore, this issue makes this research important to do. The pre-study results also showed that the construct of the four fiber variables (OPS, RI, EE, and EP) could be used in further research, as all relationships showed influence, which would later certainly be through various test procedures, as well as the need for a significant increase in the number of respondents.

\section{Material and methods}

Why the research site was chosen Dapenma-Pamsi, because this pension fund institution includes an old pension fund institution (29 years old). But the most important reason is its outstanding performance at the national pension fund level. During the last ten years, Dapenma-Pamsi's total assets have increased significantly, from Rp 1.3 trillion in 2010 to Rp 5.5 trillion until the end of 2019. Especially in 2019, although the national economy is sluggish, Dapenma Pamsi still managed to post an investment return of $\mathrm{Rp} 224$ billion. In fact, the accumulated investment yield is much greater than spending on operations and pension benefit payments, with assets at the end of 2019 reaching Rp 5.5 trillion. For the achievement, Dapenma Pamsi ranked the seventh largest pension fund manager under PT Telkom and Bank Indonesia. Dapenma Pamsi can manage pension funds well even though managing a pension fund with the number of 305 taps and 47,129 participants is not easy. Unlike other companies that only own or deal with one board of directors, Dapenma-Pamsi must deal with 310 PDAM directors as owners.

\subsection{Definition}

Here's the concept definition of all four variable variables. The occupational pension scheme (OPS) is a collective provision tool offered by companies to their workers where they finance a supplementary system with mandatory provision stipulated for workers' retirement income, so that their income increases when workers reach old age. Pension schemes are given to workers for several reasons: tax benefits, transaction costs and economies of scale, expertise, risk, morality discounts, retirement age, and underfunding (Galdeano, Olaverri, \& Huerta, 2016). Retirement intentions (RI) are the level of estimation of a worker's intention to choose and undergo retirement status, whether pr not they are full pension, part-time pension, or late retirement. Work-role theory holds that retirement intentions are a decision to relinquish all roles that a person has whether it is a job, organization, and career (Jan, \& Koster, 2013). Other opinions expressed by Prakash et al. (2019) that retirement intentions are an attitude that indicates an intention to retire before retirement age legally. Employee engagement (EE) is the level of intellectual and emotional commitment a person has to his/her company, as well as a willingness to put more effort into helping the company where he or she works to achieve the company's goals. Employee engagement is the level of commitment and willingness of workers in helping the company realize its goals and objectives (Rasli et al., 2012). Employee 
productivity (EP) is the ratio between the quantity of worker output to the quantity of worker inputs used to produce output in the company in which it works (Sang et al., 2014).

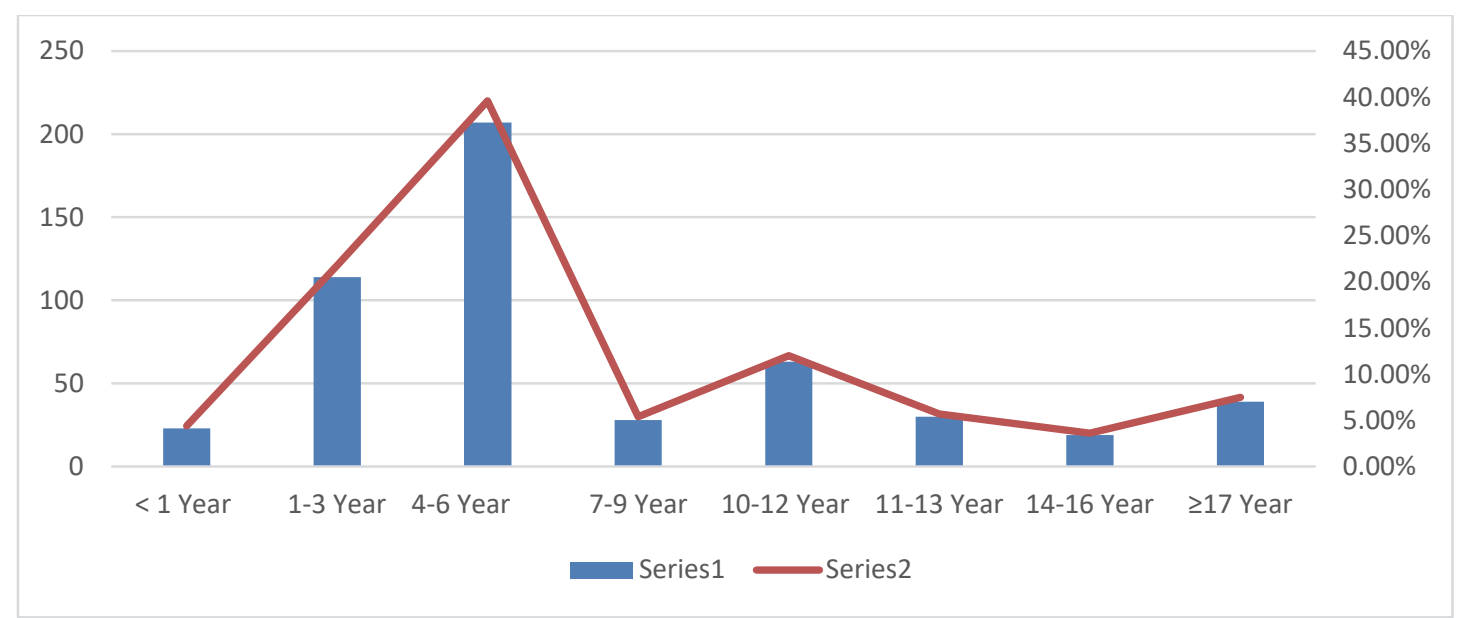

Fig. 1. Participant's Year in Pension Fund

\subsection{Hypothesis}

The hypothesis of this research hypothesis is compiled as follows:

\begin{tabular}{ll}
\hline Hypothesis 1 & Occupational pension scheme positively affects retirement intentions. \\
Hypothesis 2 & Occupational pension scheme affects employee engagement. \\
Hypothesis 3 & Occupational pension scheme affects employee productivity. \\
Hypothesis 4 & Retirement intentions affect employee engagement. \\
Hypothesis 5 & Retirement intentions affect employee productivity. \\
Hypothesis 6 & Does Employee engagement affect employee productivity ? \\
Hypothesis 7 & Occupational pension scheme affects employee productivity through retirement intention. \\
Hypothesis 8 & Occupational pension scheme affects employee productivity through retirement intention. \\
Hypothesis 9 & Occupational pension scheme affects employee productivity through employee engagement. \\
Hypothesis 10 & Retirement intentions affect employee productivity through employee engagement. \\
\hline
\end{tabular}

\subsection{Method}

This study chose a post-positivist paradigm (Creswell, \& Creswell, 2018), with this quantitative research approach, with the causal type of explanatory (Cooper, , \& Schindler, 2014). This research was conducted one time (cross sectional), in this case in 2020. The selected research location is the Pension Fund with Drinking Water Regional Companies throughout Indonesia (Dapenma-Pamsi) in six provinces in Java Island. This research instrument uses a close ended questionnaire (Cooper \& Schindler, 2014). Measuring research questionnaire using rating scale, in this case Likert Scale 1-7 with 1 which is indicated strongly disagree, and 7 which is indicated strongly agree. (Sekaran, 2000). The study population was an active participant of Dapenma Pamsi in six provinces in Java which numbered 33,936 participants. The number of samples based on the Slovin formula with $\mathrm{e}=5 \%(0.05)$ is 390 which in the field becomes 523 respondents. Telnik sampling uses proportionate stratified random sampling, meaning samples are taken randomly from each sub-category (province), but proportional to the size of the sub-number of each of those sub-categories. (Sugiyono, 2013).

All four research variables (OPS, RI, EE, and EP) are operated with second-order. OPS variables are divided into six second latent variables (dimensions), including 17 indicators (numbers 1-17) (Garcés-Galdeano et al., 2016; Loretto et al., 2000). The RI variable is operated over four second latent variables (dimensions), including 15 indicators (numbers 18-32) (Osman et al., 2016). EE variables are operated over three second latent variables (dimensions), including 17 indicators (numbers 33-49)(Bakar, 2013; Sang et al., 2014). EP variables are operated over three second latent variables (dimensions), including 11 indicators (nomor 50-60) (Beaton et al., 2009; Sultan \& Zafar, 2016; Mukundi, 2016). This research data analysis technique uses Structural Equation Modeling (SEM) analysis using Analysis of Moment Structure (AMOS) device version 23.

\section{Results and discussion}

The results showed that the direct effect of OPS on RIs was 0.558 . This means that the contribution of OPS influence to RI is 0.558 or $55.8 \%$. OPS can account for $55.8 \%$ of RIs. Remaining explanations for R $(100 \%-55.8 \%=44.2 \mathrm{I} \%)$ can be explained 
by other variables outside the OPS. Regarding the relationship/influence of OPS to RI, the t-Value or C.R value of $3,531 \geq$ 1,967. Significance $(\mathrm{P})$ three-star $(* * *)$ which means $\leq 0.05$, This means $\mathrm{H}_{0}$ is rejected and $\mathrm{H}_{\mathrm{a}}$ is accepted which means OPS has a positive and significant effect on the Republic of Indonesia. This means the first hypothesis of this study is proven. The results support theories about workers' pension schemes, pension intention theories, and previous research proving that variable occupational pension schemes affect variable retirement intentions (Ahmad et al., 2013; Dorsey et al., 1998; GarcésGaldeano et al., 2016; Orla Gough \& Hick, 2009). The results showed that the coefficient of direct influence of OPS on EE was 0.253 . This means that the contribution of OPS influence to EE is 0.253 or $25.3 \%$. OPS can account for EE of $25.3 \%$. Remaining incarnation of EE $(100 \%-25.3 \%=74.7 \%)$ can be explained by other variables outside of OPS. Regarding the relationship/influence of OPS to EE, the t-Value or C.R value is $-2,960 \leq-1,967$. Significance (P) is worth 0.003 which means $\leq$ 0.05 , This means $\mathrm{H}_{0}$ is rejected, $\mathrm{H}_{\mathrm{a}}$ is accepted which means OPS has a significant effect on the RI. That means the second hypothesis is proven. The results support a number of previous studies that occupational pension scheme variables affect employee engagement variables (Colquitt et al., 2014; Kim \& Cho, 2016). The results showed that the coefficient of direct influence of OPS on EPs was 0.332. This means that the contribution of OPS influence to EPs is 0.332 or $33.2 \%$. OPS can account for an EP of $33.2 \%$. Remaining incarnation of EE $(100 \%-33.2 \%=66.8 \%)$ can be explained by other variables outside the OPS. Regarding the relationship/influence of OPS to EE, the t-Value or C.R value of 3,531 $\geq 1,967$. Significance (p-value) 0.013 which means $\leq 0.05$, This means $\mathrm{H}_{0}$ is rejected, $\mathrm{H}_{\mathrm{a}}$ is accepted which means OPS has a positive and significant effect on EE. That means the hypothesis of number three is proven.

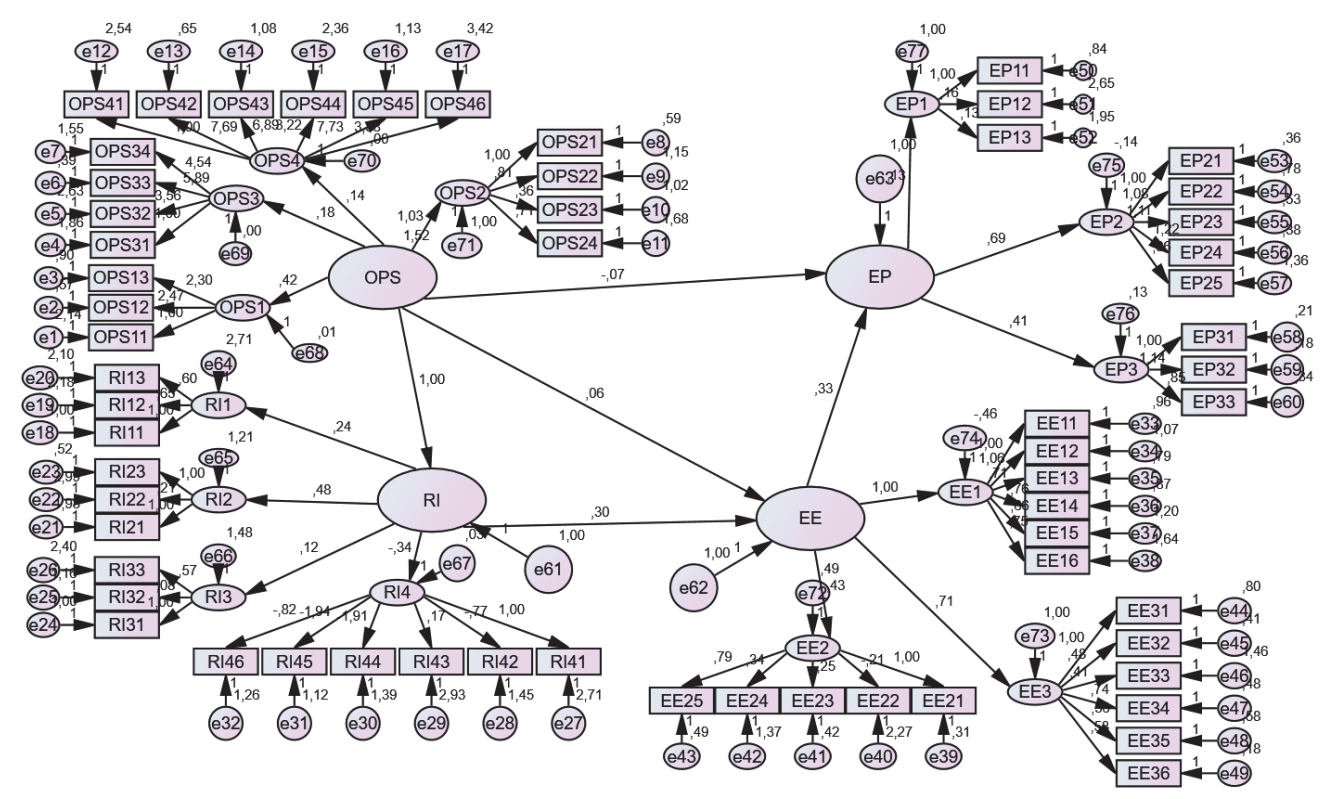

Fig. 2. Full Model of Research

The results support previous research that the occupational pension scheme variable affects employee productivity variables. (Ahmed et al., 2016b; Bossler, 2015; Colquitt et al., 2014; Dorsey et al., 1998; Mukundi, 2016; Oloke et al., 2017b; Sibanda et al., 2014). The results showed that the coefficient of RI's direct influence on EE was 0.746 . This means that the contribution of RI influence to EE is 0.746 or $74.6 \%$. OPS can account for EE of $74.6 \%$. Remaining explanations for EE (100\%-74.6 $\%=25.4 \%$ ) can be explained by other variables outside the RI. Regarding the relationship/influence of RI to EE, the value of t-Value or C.R is $8,165 \geq 1,967$. Significant $(\mathrm{P})$ three-star $(* * *)$ which means $\leq 0.05$, This means $\mathrm{H}_{0}$ is rejected, $\mathrm{H}_{\mathrm{a}}$ is accepted which means RI has a positive and significant effect on EE. That means the hypothesis of number 4 is proven. The results of this study support previous research that proves that variable retirement intentions affect employee engagement variables (Hussain et al., 2013; Saks, 2006). However, the results of this study are contrary to the results of the (Rusyandi, 2015) which indicates that there is a significant and strong negative linear relationship between employee engagement and the intention to quit. The results showed that the coefficient of direct influence of RI on EP was 0.543 . This means that the contribution of RI influence to the EP is 0.543 or $54.3 \%$. Ri can explain the EP of $54.3 \%$. Remaining explanation of EP $(100 \%-54.3 \%=45.7 \%)$ can be explained by other variables outside the RI. Regarding the relationship/influence of the RI to the EP, the t-Value or C.R value of $-3,327 \leq-1,967$. Three-star significance $(* * *)$ meaning $\leq 0.05$, which means $\mathrm{H}_{0}$ is rejected, $\mathrm{H}_{\mathrm{a}}$ is accepted which means RI has a positive and significant effect on the EP. That means the hypothesis of number 5 is proven. The results of this study support the results of previous studies that prove that variable retirement intentions affect employee productivity variables (Otube et al., 2012). The results showed that EE's direct influence on EPs was 0.787. This means the contribution of OPS influence to EE is 0.787 or $78.7 \%$. EE can explain the EP of $98.7 \%$. Remaining incarnation of EE (100\%$78.7 \%=21.3 \%$ ) can be explained by other variables outside EE. EE's relationship/influence to EP, t-Value or C.R value of $4,848 \leq-1,967$. Significance $(\mathrm{P})$ three-star $(* * *)$ which means $\leq 0.05$, This means $\mathrm{H}_{0}$ is rejected, $\mathrm{H}_{\mathrm{a}}$ is accepted which means EE has a positive and significant effect on the EP. That means the hypothesis of number 6 is proven. The results of this study 
support the results of previous research (Otube et al., 2012) EE's influence on the EP. Research of Otube et al. (2012) extension of the retirement age has a profound effect on employee productivity, which has implications for the organization's performance. An extension of the retirement age could lead to demands that workers should be involved in the company for much longer. This is understandable, given that workers who receive pension age extension contracts mean workers who have a tendency to become more involved in the company. The results showed the total influence (0.818468) of OPS on EE through RIs was greater than the indirect influence (0.253) of OPS on RIs. This means that there is a positive role of RI in mediating the influence of OPS on EE. This means that the seventh hypothesis is acceptable The results of this study support previous evidence that proves the influence of OPS on EE, OPS to RI (Ahmad et al., 2013; Dorsey et al., 1998; Garcés-Galdeano et al., 2016; Orla Gough \& Hick, 2009; Hoole \& Hotz, 2016; Hussain et al., 2013; Kim \& Cho, 2016; Rusyandi, 2015; Saks, 2006). The results showed the total influence (0.895194) of OPS on EP's through RI's was greater than the direct influence (0.332) of OPS on EP's. This means that there is a positive role of RI in mediating the influence of OPS on EP's. This means that the eighth hypothesis is acceptable. The results of this study are in line with a number of previous studies that prove that the variable occupational pension scheme against employee productivity through retirement intentions (Ahmed et al., 2016a; Colquitt et al., 2014; Cornwell \& Dorsey, 2000; Garcés-Galdeano et al., 2016; Orla Gough \& Hick, 2009; Mukundi, 2016; Oloke et al., 2017a; Otube et al., 2012; Sibanda et al., 2014). The results showed the total influence (0.593284) of OPS on EPs through EE was greater than the direct influence (0.332) of OPS on EPs. This means there is a positive role for EE in mediating the influence of OPS on EPs. This means that the ninth hypothesis is acceptable. The results of the study are in accordance with the results of previous research that proves the effect of occupational pension scheme on employee productivity through employee engagement (Ahmed et al., 2016a; Colquitt et al., 2014; Dorsey et al., 1998; Garcés-Galdeano et al., 2016; Orla Gough \& Hick, 2009; Mukundi, 2016; Oloke et al., 2017a; Otube et al., 2012; Sibanda et al., 2014). The results showed the total influence (0.970341) of RIs on EPs through EE was greater than the direct influence (0.332) of RIs on EPs. This means that there is a positive role of EE in mediating the influence of RI on EPs. This means that the tenth hypothesis is acceptable. The results of the study are in line with the results of previous studies that prove the effect of retirement intentions on employee productivity through employee engagement (Ahmed et al., 2016b; Bakar, 2013; Colquitt et al., 2014; Dorsey et al., 1998; Garcés-Galdeano et al., 2016; Orla Gough \& Hick, 2009; Hoole \& Hotz, 2016; Kim \& Cho, 2016; Kompaso \& Sridevi, 2010; Mukundi, 2016; Oloke et al., 2017b; Sharma et al., 2017b; Sibanda et al., 2014). Based on the hypothesis test, it can be stated that the results of each of the variable relationships in this study on average support the results of the previous research mentioned earlier. The results of this study also show that the construct model proposed in this study is supported by empirical research results. The results of this study are one of empirical evidence that this model is tested. This model integers variables rooted in the financial science discipline, occupational pension scheme (OPS), with variables rooted in the disciplines of human resource management, namely retirement intentions (RI), employee engagement (EE), and employee productivity (EP). In this model, variables derived from both roots of science are integrated into this research in human resource management.

\section{Conclusion}

The results support all ten hypotheses of this study. OPS proved to have a significant and significant impact on RIs, EE, and EPs directly; and OPS affects EPs through EE or RI. That means EE and RI play a positive role in mediating OPS influence to EP. Variable RI proved to have a direct and partial effect on EE and EP. The RI has an indirect effect on the EP through EE mediation. That means EE has also shown to positively play a mediation role for the effect of RI on EP. EE itself had a positive effect on the EP. The study found a research model that integrates variables rooted in financial management and human resource variables.

\section{References}

Ahmad, R., Toh, E. P. Y., \& Bujang, S. (2013). Relationship between types of benefits (leave, loan and retirement plan) and employees' retention. International Journal of Education and Research., 1(8), 1-14.

Ahmed, I. K., Abayomi, O. A., \& Nureni, S. A. (2016a). Effects of contributory pension scheme on employees productivity: Evidence from Lagos state government. African Journal of Business Management, 10(16), 384-396.

Ahmed, I. K., Abayomi, O. A., \& Nureni, S. A. (2016b). Effects of contributory pension scheme on employees productivity: Evidence from Lagos state government. African Journal of Business Management, 10(16), 384-396.

Alda, M., \& Ferruz, L. (2012). The role of fees in pension fund performance. Evidence from Spain. Finance a Uver - Czech Journal of Economics and Finance, 62(6), 518-535.

Bakar, R. A. (2013). Understanding Factors InfluencingEmployee Engagement: A Study of the Financial Sector in Malaysia. In Master thesis (pp. 1-286). https://doi.org/10.1108/02683940610690169

Beaton, D., Bombardier, C., Escorpizo, R., Zhang, W., Lacaille, D., Boonen, A., Osborne, R. H., Anis, A. H., Strand, C. V., \& Tugwell, P. S. (2009). Measuring worker productivity: Frameworks and measures. Journal of Rheumatology, 36(9), 2100-2109.

Bossler, M. (2015). The efficiency wage effect of employer provided occupational pensions. IZA Journal of European Labor Studies, 4(1), 1-17. https://doi.org/10.1186/s40174-015-0031-4

Colquitt, J. A., Lepine, J. A., \& Wesson, M. J. (2014). Improving Performance and Commitment.

Cooper, D.R., \& Schindler, P. . (2014). Business Research Methods (Twelfth Ed). McGraw-Hill International Edition. 
Cornwell, C., \& Dorsey, S. (2000). ARE PENSION-PROVIDING FIRMS MORE PRODUCTIVE ? June, 1-31.

Creswell, J. W., \& Creswell, J. . (2018). Research Design: Qualitative, Quantitative, and Mixed Methods Approaches (Fifth edit). SAGE Publications, Inc.

Dorsey, S., Cornwell, C., \& Macpherson, D. (1998). Pensions and Productivity. In Pensions and Productivity. W.E. Upjohn Institue for Employment Research. https://doi.org/10.17848/9780585277417

Garcés-Galdeano, L., García-Olaverri, C., \& Huerta, E. (2016). Occupational pension scheme: an innovative tool in HRM. Management Research, 14(2), 106-129. https://doi.org/10.1108/MRJIAM-09-2015-0611

Gough, O., \& Hick, R. (2009). Employee evaluations of occupational pensions. Employee Relations, 31(2), 158-167.

Hoole, C., \& Hotz, G. (2016). The impact of a total reward system of work engagement. SA Journal of Industrial Psychology, $42(1), 1-14$.

Hussain, I. A., Yunus, N., Ishak, N. A., \& Daud, N. (2013). The Influence of Intention to Leave Towards Employee Engagement among Young Bankers in Malaysia. International Journal of Business and Management, 8(14), 89-97.

Jan F, M.M., \& Koster, Y. . (2013). Happily ever after?: Explaining turnover and retirement intentions of older workers in The Netherlands. Career Development International, 18(6), 548-568. https://doi.org/10.1108/CDI-01-2013-0004

Kim, Y., \& Cho, Y. C. (2016). Impact Of Retirement System On Job Satisfaction And Loyalty: A Case Of The Salary Peak System. International Business \& Economics Research Journal (IBER), 15(1), 27-40.

Kompaso, S. M., \& Sridevi, M. S. (2010). Employee Engagement: The Key to Improving Performance. International Journal of Business and Management, 5(12), 89-96. https://doi.org/10.5539/ijbm.v5n12p89

Loretto, W., White, P., \& Duncan, C. (2000). Something for nothing? Employees' views of occupational pension schemes. Employee Relations, 22(3), 260-271.

Mukundi, N. E. (2016). Determinants of Employee Productivity in Private Limited Companies in Kenya: A Case Study of Equatorial Nut Processors LTD. In A Research Project (pp. 1-100).

Oloke, O. C., Oni, A. S., Babalola, D. O., \& Ojelabi, R. A. (2017a). Incentive Package, Employee's Productivity and Performance of Real Estate Firms in Nigeria. European Scientific Journal, ESJ, 13(11), 246.

Oloke, O. C., Oni, A. S., Babalola, D. O., \& Ojelabi, R. A. (2017b). Incentive Package, Employee's Productivity and Performance of Real Estate Firms in Nigeria. European Scientific Journal, ESJ, 13(11), 246-260.

Osman, Z., Ing Grace, P., Adis, A. A. A., Razli, I. A., Majid, M. R. A., \& Bujang, I. (2016). Retirement planning \& job satisfaction: Cushion to avoid bridge employment? Asian Social Science, 12(1), 30-41.

Otube, R. H., Kwasira, J., \& Kipchilat, C. (2012). An assessment of the effects of retirement age on organizational productivity : A case of Kenya. International Journal of Social Science and Research, 3(10), 1547-1550. www.ijsr.net

Prakash, K. C., Oakman, J., Nygård, C. H., Siukola, A., Lumme-Sandt, K., Nikander, P., \& Neupane, S. (2019). Intention to retire in employees over 50 years. What is the role of work ability and work life satisfaction? International Journal of Environmental Research and Public Health, 16(14). https://doi.org/10.3390/ijerph16142500

Rusyandi, D. (2015). Employee Engagement Toward Intention To Quit With job Insecurity As Moderating Variable At Goverment Bank In Bandung City. First International Conference on Economics and Banking, 318-325.

Saks, A. M. (2006). Antecedents and consequences of employee engagement. Journal of Managerial Psychology, 21(7), 600619. https://doi.org/10.1108/02683940610690169

Sang, H., Warioguyo, \& RomanusOdhiambo. (2014). The Moderating Influence Of Employee Engagement On The Relationship Between Labour Productivity And Performance. International Journal of Advanced Research in Management and Social Sciences, 3(9), 10-23.

Sekaran, U. (2000). Research Methods for Business Students (Fourth Edi). John Wiley \& Sons, Inc.

Sharma, A., Goel, A., \& Sengupta, S. (2017a). How does Work Engagement vary with Employee Demography?: - Revelations from the Indian IT industry. Procedia Computer Science, 122, 146-153. https://doi.org/10.1016/j.procs.2017.11.353

Sharma, A., Goel, A., \& Sengupta, S. (2017b). How does Work Engagement vary with Employee Demography?: - Revelations from the Indian IT industry. Procedia Computer Science, 122, 146-153. https://doi.org/10.1016/j.procs.2017.11.353

Sibanda, P., Muchena, T., \& Ncube, F. (2014). Employee engagement and organisational performance in a public sector organisation in Zimbabwe. International Journal of Asian Social Science International Journal of Asian Social Science, 4(1), 89-99. http://www.aessweb.com/journals/5007

Solem, P. E., Syse, A., Furunes, T., Mykletun, R. J., De Lange, A., Schaufeli, W., \& Ilmarinen, J. (2016). To leave or not to leave: Retirement intentions and retirement behaviour. Ageing and Society, 36(2), 259-281.

Sugiyono. (2013). Metode Penelitian Kombinasi (Mixed Methods) (Cetakan ke). Penerbit Alfabeta.

Sultan, M. F., \& Zafar, M. R. (2016). Office Design and its impact on employees' productivity: Evidence from Islamic Banks of Karachi. International Journal of Scientific and Research Publications, 6(6), 335-342. www.ijsrp.org

Wang, P., Zhang, M., Shand, R., \& Howell, K. (2018). Retirement, Pension Systems and Models of Pension Systems. SSRN Electronic Journal, 1-17. https://doi.org/10.2139/ssrn.2476907

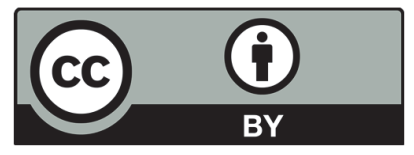

(C) 2021 by the authors; licensee Growing Science, Canada. This is an open access article distributed under the terms and conditions of the Creative Commons Attribution (CC-BY) license (http://creativecommons.org/licenses/by/4.0/). 